\title{
Dubravka Oraić Tolić's Thoughts on Antun Gustav Matoš
}

ABSTRACT. Dujić Tatjana, Dubravka Oraić Tolić's Thoughts on Antun Gustav Matoš. „Poznańskie Studia Slawistyczne” 7. Poznań 2014. Publishing House Science and Innovate, pp. 309-321. ISBN 978-83-63795-79-5. ISSN 2084-3011.

The purpose of this appendage (addendum) is to study a position of the female subject in the fictional prose of Antun Gustav Matoš through the reading of Dubravka Oraić Tolić. This research has shown that female subjects carry, or better to say, possess all features of Matošs poetic expression, therefore it is possible to sort them into three different models: woman-mother, woman-aesthetic creation and femme fatale.

Keywords: landscape; irrationality; flaneuristic subjectivity; lyricization; aestheticization; models of a female subject

\section{Prose of Antun Gustav Matoš}

According to Dubravka Oraić Tolić, Matoš's prose belongs to two literary genres: fictional prose (novellas) and nonfictional prose (all other prose forms: travelogues, feuilletons, essays, critiques of literary texts and other artwork, and autobiographical texts) (Oraić Tolić 2013: 53). The reason why it is impossible to analyse his works within the parameters of existing genres is that, with his highly poeticized prose on the one hand and high aesthetic principles in his discourse on the other, he established new literary genre systems. These systems, exclusive to A.G.M., did not happen accidentally but intentionally. He created a Matoš-specific aesthetic construct, always emphasizing his own uniqueness and individualism. His novellas can be classified according to their themes, prevalent motives, and types 
of motivation (i.e. realistic, social, external, i.e. modernist, motivated by the literary process). Dubravka Oraić Tolić distinguishes between two basic narrative sub-groups in Matoš's prose: 1. short stories with impressionist elements; 2 . short stories with dominant symbolist elements often intertwined with fantastic and grotesque details.

A.G.M.'s literary evolution happened in a historically reverse chronological order. Pre-avant-garde elements, fantasy prose, and ever-stronger aesthetic elements in his early work all announced avant-garde. Although Matoš announced avant-garde with his use of various implicit forms, he also vehemently denied it „when avant-garde stepped out of the realm of aestheticism and quiet stylization and into the harsh reality of programs and manifestos that called for violence" (Oraić Tolić 2013: 28). His novellas with powerful story lines, depicting situations found in actual social situations or possibly psychologically motivated, were not written in the spirit of realism. The poet was influenced by both cultural content and factual knowledge; he was subjected to a mixture of impressions, experiences, and intellectual stimuli.

Miroslav Šicel emphasizes that A.G.M. ,reached his highest literary success with novellas in which poetic motifs of amorous yearning and pronounced poetic intonation actually contribute to the creation of a certain type of a prose poem of" (Oraić Tolić 2005: 6). Examples of this are the novellas: Cvijet sa raskršća (A Flower at the Crossroads) and Balkon (The Balcony).

A person who gets used to clouds instead of a roof, to hills instead of stairs, to woods instead of rooms, one who heard the voice of the Lord above the waters cannot live in houses. The sea and the wind are my bow and my piano, flowers and stars are letters in my book, silence is my reader (Matoš 1993: 238).

I have nothing except love, but it does not drip from my chest like honey from a mature hive; it is stronger and more faithful than our old balcony, warmer than the sun and deeper than midnight darkness. Listen to the leaves rustling for us; listen to the birds sighing as we fall asleep; listen to the double reed aulos sobbing in the silent branches! (Matoš 1993: 226).

A gap between reality and fantasy, the real and the unreal, fact and dream, object and subject characterize symbolist novellas, as opposed to impressionistic ones. Among these, several types of novellas stand out: 
1. Novellas in which two worlds clash (Moć savjesti [The Power of Conscience], Miš [The Mouse], Camao, Iglasto čeljade [A Needle-like Creature], Duševni čovjek [The Man With a Soul], Osveta ogledala [The Revenge of Mirrors]).

2. Novellas in which the world of fantasy and ideals remains out of reach (Lijepa Jelena [The Beautiful Jelena]), Balkon, Put u ništa [Journey to Nothing], Cvijet sa raskršća.

3. Novellas depicting a transcendental world of fantasy and dreams, in which a man is just a part of the universe (Samotna noć [A Lonely Night], O tebi i o meni [About You and Me], Sjena [A Shadow]) (Oraić Tolić 2013: 51).

Since Matoš appeared on the literary scene at the time when social and national issues abated and made room for psychological studies of human personalities, it does not come as a surprise that A.G.M. did not combine elements of real life into a realistic whole but concentrated on his own vision of the world. Influences of the E.A. Poe's irrational and morbid world are easily recognizable in count Andrija's fear or in the suicidal curiosity of the Iglasto čeljade, but morbidity and horror, imagination and dreams maybe best describe the similarity between Matoš and Poe, as exemplified in the novella Samotna noć (Bašić 1970: 393-412).

I stumble aghast into one, then another home: all dead, all died tonight. I wandered, staggered over bodies of dead noblemen and noblewomen, craftsmen, and soldiers. In the courtyards dead cattle and poultry lay sprawled. Across bare steps of a church dead monks clad in black lay like musical notes in an old breviary. But that chant was mute and dark. (...) I stepped into blackness, into a condemned place, into Deathtown (Matoš 1993: 207).

Thematically, Matoš' novellas deal with topics of love or death. In her study Čitanja Matoša (Reading Matoš), Dubravka Oraić Tolić divides lovethemed novellas into two types:

1. Unreachable ideals of love and beauty due to the conflict between fiction and faction (Miš, Camao, Balkon).

2. Love as eternal yearning (Cvijet sa raskršća) (Oraić Tolić 2013: 52).

Novellas of both types have unhappy and tragic endings due to either the loss of the ideal of love and beauty or the hero's realization the search, 
the adventure, is more important than the discovery and realization of the absolute ideal. Death is depicted as a part of life, as a consequence of the conflict between dreams and reality, as a flight of sorts and a way to express one's dissatisfaction with the material world. His preoccupation with death is evident in the novellas Samotna noć, O tebi $i$ o meni and Sjena (A Shadow).

Millions step out of the dark, walk in the dark and go back into the dark. They mock, suffer, slaughter, kill. (...) Love is hatred to them. God is fear. Their emperor is hunger and passion their empress. They ail and die with a curse with which they were born. (...) because I emerge from the dark, tip toe in the dark, and die in the dark. The dark pathway of darkness into more darkness (Matoš 1967: 223).

Dubravka Oraić Tolić claims that the unusual plots, told in a fast rhythm and in ,enervating” combinations, are also an expression of the deep ontological crisis, which itself was a result of the crisis of rationalism and positivism in the European art and culture during modernism. Modernist sensibility claimed aestheticism as the only goal of a literary text. Along the same lines, narrative texts lost clear story lines as a consequence of broken cause and effect relations, as exemplified in fusions of dreams, fantasy, and transcendental states. Another consequence of nonlinear plots is the disappearance of clear genres limits, i.e. poetization or dramatization of prose.

Oh, how painful it is for a human to avoid another human!

Because I look for Him, but he doesn't exist.

Because I look for the soul, but it doesn't exist.

Because I look for the law, but it doesn't exist.

Because I look for justice, but it doesn't exist.

Because I look for the truth, but it doesn't exist.

Because I run away from people and catch a man.

Because I run away from myself and keep turning on my heel around my own damned axis

(Matoš 1967: 224).

In Jesenska idila (The Autumn Idyll), we see dramatization of prose as a result of genre blending. A butterfly, a wilted rose, a pair of trousers, a shirt, a sock, a wall, a table, and water all take part in a conversation. In 
this way a fantasy story taking place between life and death, dream and reality is created and includes laments about women, love, and homeland.

Chair: May man be damned, his own and everybody else's enemy.

All: Damn him, damn him!

Shoe: Who has cried more than me because of him? He bothers and tortures me, he wears me out and tears me apart.

Sock: Oh, shoe, sweetheart! You must have forgotten me (Matoš 1967: 280).

Matoš does not follow specific literary rules. He approaches a literary work as an artistic phenomenon with specific and unique features. In the culture of modernism, which was introduced by A.G.M., identity is understood as an ontological entity. A.G.M. feels as an outsider in his own national culture, and due to displacement of his own choosing, he lives in both external and internal exiles. His characters are not only psychologically removed from the world; he stresses their idiosyncrasies and their shift away from familiar reality (the characters live away from their homelands and travel to distant places). He often includes his personal opinions, view and autobiographical elements when creating characters. In his symbolist novellas, his autobiography resides in the displacement of the characters and their status as outsiders, which corresponds with Matoš's own exile, and in the portrayal of the artist as a misunderstood person.

Lacković was not a rebel, on the contrary, but the notion that he, a decent and hardworking human being, was not able to find food and shelter, made him so furious that he stretched out his hand as if wanting to strangle the dark night. He forgot that he had taken the poor girl with him to use her as a cheap but excellent model. He secretly sobbed all the way because he remembered his mother, a poor woman living on a small pension by the sea; he also remembered a good, beautiful, poor girl who he wouldn't be able to marry for a long time because both of them were like those tears falling onto his sleeve (Matoš 1967: 321).

When we take a closer look at the characters in Matoš's prose, we can conclude that they are modern individuals who carry the burden of their intellectual or artistic ideologies. They are failed students, eccentrics, autistic individuals, or individuals who lose touch with empiric reality by 
withdrawing inward, into the world of dreams or imagination. Their psychological motivation is based on the immersion into the world of their own subjectivity.

Landscape is present in every Matoš's work as an independent topic. (...) For Matoš, individual landscapes are associative of a variety of subjects. This particular impressionist characteristic, in which the landscape, as a cause of emotional excitement, has the ability to trigger sparkling associations about the world. It is the landscape where Matoš found an original and basic inspiration for his entire literary output (Šicel 1966: 55).

A.G.M. combines the direct experiences of nature with other stylistic elements, creating a synesthetic unity.

Flowers sing colourful pastorals with scents of daisies and Midsummer Day flowers. The lake whirrs a silver hymn, sable corals hum from dark forests. In the sky a blue silk flag crinkles. Playful girls jump out of thick bushes, groves, and forests, whipping the air with their sweaty bacchanalian hair. (...) Have you seen and do you love the ocean? I've heard it in Brittany. I saw it with my ear (Matoš 1967: 341, 343).

Antun Barac sees Matoš’s landscape as an expression of inseparable connection of Matošs's identity to his homeland.

Matoš started to cultivate our landscape - not only because he wanted to create beautiful images, but because he deemed the man a part of the soil, tied with invisible ties to the grass, the tree, and the stone - in short, to all that already shaped his view of the world in childhood (Oraić Tolić 2013: 357).

\section{Types of Female Subjects in Fictional Prose}

In her study Čitanje Matoša (Reading Matoš), Dubravka Oraić Tolić reflects upon his gender policy and literary work by researching his worldview, and stylistic representations and ideas about women, limiting her research to feuilletions and reviews. The purpose of this reading is to shed light on the position of women in A.G.M.' novellas. 
Modern culture is based on a strong gender dualism. Strong differentiation between genders and barriers between men and women in Matoš's work are due to social and cultural circumstances and the ontological crises occurring at the turn of the $19^{\text {th }}$ to the $20^{\text {th }}$ century. They did not take part in discussions, did not make independent decisions. A woman's most important and most sacred duty was to give birth and raise children.

It did not even occur to Matoš to try to define the relationship between sexes as a specific and complex relationship between human beings in general, as a relationship in which equality plays an important but not the only role, a relationship in which conflict cannot be completely eliminated because it is an encounter of two separate personal freedoms, a relationship rife with absurdities and paradoxes, so that national solutions are not the best solutions (Lasić 1986: 173).

„Symbolic androgynous characters, products of modern culture: geniuses, dandies, bohemians, flaneurs, supermen, and independently wealthy men" played an important role in reducing down gender roles during modernism (Oraić Tolić 2005: 89).

Dubravka Oraić Tolić explains bohemianism and describes a bohemian as an androgynous society member. She emphasizes that it is a male ,,antihero who consciously secludes himself from the society by unconsciously choosing the marginalized female position" (Oraić Tolić 2005: 95).

A bonnet hid in a mess of long, tired hair, like winter clouds that hide the moon. Galoshes instead of shoes. Under the short yellow, once expensive, summer overcoat, hung tattered scraps of a ragged topcoat like wings of a bat. Face musty, damp, yellow (Matoš 1967: 327).

According to the interpretations of gender ideologies, the identity of a flaneur is „not «male», universal, complete, and strong, but «female», private, fragmented, fluid, and a little bit suspicious as are the ladies with whom he shares literary space" (Oraić Tolić 2005: 101).

Therefore, modern artists offer new spaces, where a person can saunter and enjoy idleness. Along with particular areas of a city (railway stations or exhibition halls), surreal worlds became spaces through which one can wander aimlessly. 
The heroine appears in different constructs of nature and fantastic experiences. Dubravka Oraić Tolić emphasizes Matoš’s inconsistent evaluation of the feminist movement, whose first wave occurred at the turn of the $19^{\text {th }}$ into the $20^{\text {th }}$ century. He sometimes speaks in favour of female emancipation, and at other times he enters into heated arguments with feminists.

Stanko Lasić brings up A.G.M.'s view of Marija Jurić Zagorka's work and a firm stand against feminism, ,He rejects all feminist demands as «philosophising», «fantasizing», «empty jabber, babble, claptrap», «superfluous, ridiculous, and silly statements»" (Lasić 1986: 176). In the same text, he remembers Matoš's article in „Ognjište” (,The Hearth”), in which the woman is depicted as a mother and a spouse, the same article where he emphasizes that a woman is poetry and loyalty, and everything else is prostitution, which is a form of struggle for emancipation.

His life was filled with women, who sometimes made his life enjoyable and at other times caused anguish. This is why A.G.M. both praised and demeaned women - it probably depended on his latest experience.

The woman is as we want her to be: a slave in the East; Messalina in the Rome of emperors and gladiators; the actress Mericourt among the Jacobites; George Elliot in the company of Millo and Spencer; Sonja Kovalevsky in Russia on the New Path. This is why the woman is often a symbol of her society and time. Schopenhauer's romance writer is the best interpreter of pessimism; Goethe's counsellor the best interpreter of her son's universal spirit. Women are our mirrors broken to no avail by those furious at their own disfigurement (Jelčić 1984: 224).

Matoš's female images embody all classic concepts of the woman and the female principle, ranging from: seductresses to mothers, from women symbolizing love to women, bearers of evil and death. Female characters in his short stories are marked by the conflict among feminist ideas, established gender roles, and the author's political view point that a woman depends on her husband. By limiting physical and psychological freedom and supressing creative potentials of women, the conservative environment and patriarchal beliefs produced the concept of the ideal woman: the woman-the mother-the homeland.

The best example of a personified homeland and idealized woman-mother-homeland could be the character of Pogačićka-a female character that does not fear even certain death in order to defend her beliefs and ideals. 
Only now, when she felt lonely and abandoned, observing more and more clearly furious, stupid faces and naked swords, the old woman felt terrible fear. Something bit her deep in the chest, her knees trembled, the two or three remaining teeth chattered, and her eyes fogged over. She cringed and started biting her nails. It seemed to her that the chubby officer with a pointed moustache was giving her a nasty, evil look. Down, old woman! - somebody shouted.

And, she, all shaken, stood up bravely and threw a prayer-like look at the shiny nobleman (Matoš 1993: 132-133).

The mother as a type of a weak woman, a keeper of the hearth and patriarchy, outgrows these roles to embody the homeland as the highest ideal. Instinctive behavioural blueprints determine the archetype of the woman and mother, while wishes and needs of women are secondary to social norms. The character of the woman-mother-homeland does not stress either her physicality or her passion unless it is meant as a means to a higher end.

Another female type in Matoš's novellas is a woman who is aware of her beauty and uniqueness. For him, a woman is primarily a beauty and a lover.

Because happiness resides in beauty, and everything is beautiful and therefore cannot be defined. Everything is beautiful, and no pain would last and carry in itself the kiss of the eternal and omnipresent goddess, Beauty (Jelčić 2004: 309).

A.G.M. wrote the following lines to the actress Ljerka Šram, but they can be applied to any woman whose beauty, gentleness, and fragility are metaphors for purity and moral ideals.

She is as beautiful as a work of art, a statue or a live painting. She is like those fragile and precious objects, like a crystal, an emerald, or a ruby, whose shadow shines more brightly than dark lights; she is like those rare Chinese or Persian flowers that can only struggle to survive in our climate under the artificial warmth of a glass roof. She is an instinct, a child, an ingénue. Her appearance is a work of art, and that is why her physiognomy is doll-like; she has the face of a Velasquez infanta, like angels and all those creatures that do not know about darkness and evil because they remain eternally childlike. She is like a blissful sunny day, spreading shiny warmth like Mozart's music and a Botticelli painting-dispersing beauty like purple suits which give a red glow to everything around. She is beautiful, and beauty is a gift, the genes of a woman that enchant like an ideal, like poetry (Oraić Tolić 2013: 201). 
Women sometimes reject the socially imposed gender roles, and sometimes they appear in the novellas as symbols of unfulfilled love. However, beauties are still unable to enchant and seduce; they are innocent and naive deep down; they are unattainable and seem very fragile in real world. This is why they are placed in illusory spaces of dreams and imagination, in fantastic settings in which their beauty and naiveté reach a complete aesthetic realization.

A young girl sat on the moss by my head, so pale and tender as if she'd seen only white moonlight, as if she'd breathed evening flowers, as if she'd played only with nocturnal, dark, velvety butterflies. Golden-red tresses fell loosely down her tender, snow-white, naked neck, and long, heavy ringlets shook on her weak, young, budding bosom. (...) On her feet white shoes that had never seen mud. She holds a greyhound on a leash, which lies with its narrow head between its outstretched legs. (...) If it had been nighttime, I would've thought I had seen a sleepwalker, a somnambulist (Matoš 1967: 341-342).

This type of female beauty connects reality and fiction within imaginary spaces and fantastic and unrealistic landscapes in a text, and so female characters become carriers of the highest aesthetic ideals. Their personalities are not marked by either strong individualism or stereotypical roles. They do not give in to social roles, but they do not make their own decisions either. Beautiful women are a realization of beauty, a perfect visual sensation. Selfawareness gives women power. A self-conscious woman makes her own decisions, expresses her wishes, and shows her abilities. Psychologically stronger women are emancipated in the character of the seductress, who still experiences social disapproval because of the emphasis on her physicality and sensuality. This is why the characters of artists, actresses and prostitutes are often superimposed on this type of a woman.

Women artists, conceited ladies, dancers and actresses represent the third type of an aesthetic ideal. The traits of these characters are eroticism, sensuality, and physicality, i.e., the beauty of bodily experience. Characters of the female artists often become femmes fatale.

The rhythm of your stature is the sleekness of a snake that isn't aware how horrible its stare and poison are. And the snake, as cold as an ancient noble revenge, wrapped 
itself around my chest and my heart, and my spellbound, cursed, and exhausted soul already yearns for the scent of sin, destruction, death, lust, hell, damnation. Dry lips already tremble with longing for the apple, the apple of Eve and Pharid's goddesses, for the red sting of a kiss and of death. In material terms, it does not know what love is. As a sick cell, the daughter of Ganesh does not know the law of moral gravity. She is the sun and knows that she is the sun whose play resembles that of tragic noble planets before the Revenge, before the Revolution. I, the adorer of nature, can see in Her all her terrible beauty of great indifference... (Matoš 1967: 352-353)

Strong women seduce with the uniqueness of their gender and realize their plans with the freedom they feel and live. They are wise, intelligent women who follow their instinct for self-realization, and disregard social disapproval. In this way the character of the femme fatale combines the „male" public and the ,female" private elements. Women objects thus become women heroes. „Like water, she can refresh and cheer you up, but also destroy, drown the unskilled, weak swimmer" (Oraić Tolić 2013: 200).

I considered her a foreign beauty, some tycoon's lover, a young artist still unknown in Paris (...). She was bored by the gilded cage, the sporting scene, the world of finance and diplomacy and wanted to experience the adventure of artist's love. (...) When I offered her my hand, I felt the heroism of love. If she had told me to kill somebody or to kill myself, I would have obeyed without a second thought. (...) Today I am a wretched, tired man of thirty, the age when others start to live. In prison I got used to terrible faults and atrocities, lost all my teeth and my sight, damaged my lungs and health, and lost every trace of enthusiasm for women, without which I cannot be an artist (Matoš 1993: 213-214, 218).

Heroines in Matoš's fictional prose carry all signature traits of his poetic expression (poetization, anesthetisation, specific understanding of landscapes, synesthetic experiences, the inseparable connection between personality traits and the land, interconnectedness of dreams, imagination, and transcendental states, irrationality, autobiographical traits, flaneuristic subjectivity, stylistic pluralism). They are the soul of his texts, and the text, indeed, is life.

A woman was neither a form of entertainment nor an ideal to me but life itself, the very contents of life. (...) was only interested in women in my life. She was my 
wine, ideal, everything. I read only about women, I dreamed only of women. (...) At first, drunk on beautiful female shapes, I didn't notice that all my lovers were mostly models and lovers by profession-creatures without either brains or a soul. All that is alive does not necessarily live. I became sad, weak, apathetic and realized that the sheer beauty of form, however alive, has no contents if it lacks a soul, and that carefree enjoyments in an atelier are not what I have always wished for (Matoš 1993: 208-210).

From the above mentioned it is clearly stated that the power of Matošs art lies in linking subjective and intimate with objective and general. He creates his own aesthetic construction connected with ideas of social and cultural opportunities, contrapositions of parentage aspects and an ontology crises at the transition of $19^{\text {th }}$ to $20^{\text {th }}$ century. Hence his literary work contains very broad panorama of themes and motives, starting with flaunting experience of life, gentle humour and anecdotism through secret and dark corners of a soul to grotesque situations and pictures, bizarre themes and notional-symbolic motivations. Those are the things that make Matoš peculiar and unattainable.

Translated into English by Ksenija Mitrovich

\section{Literature}

Barac A., 1934, Predavanja o A.G. Matošu, in: idem, A.G. Matoš. In Memoriam, o dvadesetoj godišnjici pjesnikove smrti, Zagreb, p. 11-24.

Bašić S., 1970, Matoš prema Edgaru Allanu Poeu, in: Hrvatska književnost prema evropskim književnostima, ed. A. Flaker, K. Pranjić, Zagreb.

Jelčić D., 1984, Matoš, Zagreb.

Jelčić D. (ed.), 2004, Kristali duha: misli i pogledi Antuna Gustava Matoša, Zagreb.

Lasić S., 1986, Književni počeci Marije Jurić Zagorke, Zagreb.

Matoš A.G., 1967, Antun Gustav Matoš, ed. D. Tadijanović, M. Matković, „Croatica” no. 24-25, p. 111-120.

Matoš A.G., 1993, Izbor iz djela Antuna Gustava Matoša, ed. V. Frangeš, Zagreb.

Oraić Tolić D., 1980, Pejzaž u djelu A.G. Matoša, Zagreb.

Oraić Tolić D., 1986, Matoš i avangarda, „Croatica” no. 24-25, p. 111-120.

Oraić Tolić D., 1993, Hrvatski književni Gesamtkunstwerk, „Republika” no. 3-4, p. 82-89. 
Oraić Tolić D., Kravar Z., 1996, Lirika i proza Antuna Gustava Matoša, Zagreb.

Oraić Tolić D., 2005, Muška moderna i ženska postmoderna, Zagreb.

Oraić Tolić D., 2012, Matoševe metropole - Matoševe provincije, „Književna smotra” no. 163 , p. 123-129.

Oraić Tolić D., 2013, Čitanja Matoša, Zagreb.

Šicel M., 1966, Matoš, Rijeka. 